\title{
Effects of transpositional muscle flaps transfected with vascular endothelial growth factor gene in the treatment of experimental osteomyelitis
}

\author{
Mahir Aliyev, M.D., ${ }^{1}$ Andaç Aykan, M.D., ${ }^{2}$ Muhitdin Eski, M.D., ${ }^{2}$ Nuri Arslan, M.D.,, \\ Bülent Kurt, M.D., ${ }^{4}$ Mustafa Şengezer, M.D. ${ }^{2}$
}

\author{
1Department of Plastic and Reconstructive Surgery, Military Hospital, Baku-Azerbaijan \\ ${ }^{2}$ Department of Plastic and Reconstructive Surgery, Gülhane Military Medical Academy, Ankara-Turkey \\ ${ }^{3}$ Department of Nuclear Medicine, Gülhane Military Medical Academy, Ankara-Turkey \\ ${ }^{4}$ Department of Pathology, Gülhane Military Medical Academy, Ankara-Turkey
}

\begin{abstract}
BACKGROUND: Based on the angiogenetic and stimulating effects of bone healing and formation of vascular endothelial growth factor (VEGF), the present study was designed to assess the efficacy of VEGF gene application in the management of experimentally induced osteomyelitis.
\end{abstract}

METHODS: Thirty-two male Sprague Dawley rats were divided into 4 groups, and osteomyelitis was induced in the left tibial bones. Group I $(n=8)$ was designated as a control group, and, after the induction of osteomyelitis, no treatment was applied for a period of 4 weeks. Group $2(n=8)$ received only antibiotic treatment for 4 weeks following induction of osteomyelitis. In Group 3 ( $n=8)$, proximally pedicled gastrocnemius muscle flap was transposed over the osteomyelitic region following induction of osteomyelitis and antibiotic treatment applied for a 4-week period. In Group $4(n=8)$, VEGF gene-transfected gastrocnemius muscle flap was transposed over the osteomyelitic region following identical antibiotic regimen applied for a 4-week period. For each group, body temperature, white blood cell (WBC) count, and radiological and histological parameters were evaluated.

RESULTS: Body temperature and WBC count remained high in the control group, but returned to normal in Groups 2 , 3, and 4 after the third week of treatment. Statistical analysis of the total scores of radiological and histological results revealed significant differences between Groups I and 3, Groups I and 4, Groups 2 and 3, and Groups 2 and $4(p<0.05)$. Regarding radiological parameters of abscess and sequester, and histological parameter of abscess, statistically significant differences were found between Group 4 and the other groups $(p<0.05)$.

CONCLUSION: The efficacy of the VEGF gene-transfected muscle flap in the management of experimental osteomyelitis was proven by the results of the present study.

Keywords: Gastrocnemius; muscle flap; osteomyelitis; transfection; VEGF gene.

\section{INTRODUCTION}

Osteomyelitis is an inflammatory process accompanied by bone destruction and necrosis caused by infection. ${ }^{[1,2]}$ The

Address for correspondence: Andaç Aykan, M.D.

Gülhane Askeri Tıp Akademisi, Plastik, Rekonstrüktif ve Estetik

Cerrahi Anabilim Dalı, 06010 Etlik, Ankara, Turkey

Tel: +90 312 - 3045407 E-mail: andac_aykan@gata.edu.tr

Qucik Response Code Ulus Travma Acil Cerrahi Derg

2016;22(3):205-2/4
doi: $10.5505 /$ tjtes.2015.37888

Copyright 2016

TJTES most commonly isolated pathogen is Staphylococcus aureus (S. aureus). ${ }^{[1]}$ Bacterial toxin production and host inflammation frequently damage the blood supply and result in bone necrosis. ${ }^{[3]}$ The devitalized bone acts as a foreign body, with sustained infection in spite of long-term antimicrobial therapy. The high rates of antimicrobial therapy success in the treatment of most infectious diseases have yet to be achieved in the treatment of osteomyelitis.

Osteomyelitis tends to be chronic, causing persistent morbidity and major financial burden, and substantially affecting quality of life. Current management of osteomyelitis includes a combination of long-term antibiotic therapy, and recurrent surgical debridement of necrotic bone and infected tissue. ${ }^{[1]}$ However, these methods are not satisfactory and may re- 
sult in failure in $31 \%$ of patients. ${ }^{[4]}$ Therefore, more effective treatment modalities are needed.

Local or free muscle flaps are commonly used in the treatment of osteomyelitis with soft tissue defect due to trauma or vascular insufficiency localized on the lower extremity. ${ }^{[5-8]}$ Muscle flaps have long been considered very useful for filling defects, revascularizing tissue, and controlling chronic infection. ${ }^{\text {[9] }}$ It is shown that experimental flaps that include the muscle have a greater resistance to bacterial inoculation than random-pattern skin flaps. ${ }^{[10]}$

Alternative treatment modalities that can provide neo-vascularization may be considered to treat diminished vascular supply to the bone caused by osteomyelitis. It is known that vascular endothelial growth factor (VEGF) plays an important role in new bone formation and neo-vascularization. [11-13] Several experimental studies have indicated that administration of exogenous VEGF can induce angiogenesis and improve the survival of flaps. ${ }^{[14,15]}$ However, the low half-life, enzymatic inactivation, and the need to carrier molecules are the most important factors challenging the use of exogenous growth factors. Recently, gene therapy has been utilized to avoid the need for daily injections and overcome these disadvantages. ${ }^{[16,17]}$

Based on the angiogenetic and stimulating effects of bone healing, and the formation of VEGF, the present study was designed to assess the efficacy of VEGF gene application to the muscle flap in the management of experimentally induced osteomyelitis.

\section{MATERIALS AND METHODS}

\section{Animals}

Thirty-two adult, male Sprague Dawley rats weighing 320-360 $\mathrm{g}$ each were used. Prior to surgery, rats were acclimated to their new environment and fed a standard laboratory diet. The animals were housed in single room, with a consistent room temperature. The Ethics Committee approved the study protocol (KS-06/3I), (Scientific Research Board and Ethics Board of Animal Experiments, protocol number: KS06/3I). All experiments were performed in accordance with the approved protocol.

\section{Study Design}

Animals were divided into 4 groups, and osteomyelitis was induced in the left tibial bones. Group I $(n=8)$ was designated as a control group. After 2 weeks that followed the induction of osteomyelitis in the left tibia, no treatment was applied for a period of 4 weeks. Cortical bone defects of equal size had been drilled in the right tibias of control group animals, but no bacterial inoculum was injected. Group $2(n=8)$ received only antibiotic treatment (intramuscular gentamicin, $4 \mathrm{mg} / \mathrm{kg}$ ) for 4 weeks following 2 weeks of induction. In Group $3(n=8)$, after 2 weeks of induction, a proximally pedicled gastrocnemius muscle flap was transposed over the osteomyelitic region, and antibiotic treatment (intramuscular gentamicin, 4 $\mathrm{mg} / \mathrm{kg}$ ) was administered for a period of 4 weeks. In Group $4(n=8)$, after 2 weeks of induction, a VEGF gene-transfected gastrocnemius muscle flap was transposed over the osteomyelitic region, and the same antibiotic regimen was applied for a period of 4 weeks (Fig. I).

\section{Bacterial Suspension}

S. aureus (strain 25923; American Type Culture Collection, Manassas, VA, USA) was used as the pathogen. Preparation of bacterial suspension was achieved in accordance with reported procedure. ${ }^{[18]}$ Briefly summarized, the strain was cultured for 24 hours at $37^{\circ} \mathrm{C}$ on a blood agar plate. Bacterial cells were suspended in sterile saline until final optical density of 0.18 was achieved, as indicated by absorbance measurement of $600 \mathrm{~nm}$ by spectrophotometer (Novaspec II; Amersham Pharmacia Biotech, Inc., Piscataway, NJ, USA). Based on optical density, a suspension containing approximately $3 \times 10^{8}$ colony-forming units (CFU)/mL of $S$. aureus was used as inoculum.

\section{Surgical Procedure}

Anesthesia was induced with a mixture of $10 \%$ ketamine hydrochloride $(90 \mathrm{mg} / \mathrm{kg})$ and $2 \%$ xylazine $(10 \mathrm{mg} / \mathrm{kg})$ via intramuscular injection. Skin preparation involved shaving and disinfection with $10 \%$ povidone-iodine solution.

\section{Induction of Osteomyelitis}

After $\mathrm{I}-\mathrm{cm}$ skin incision was made, the left proximal tibia was exposed. Two holes with I-mm diameters were drilled at distance of $7 \mathrm{~mm}$ on the cortical bone, and the medullar cavity was exposed. Immediately afterward, bacterial inoculum $\left(3 \times 10^{8} \mathrm{CFU} / \mathrm{mL}\right.$ of $S$. aureus) of $20-\mu \mathrm{L}$ volume was injected into the medullar cavity. The drilled hole was sealed with bone wax (Braun; Aesculap AG \& Co., Tuttlingen, Germany). Skin edges were reapproximated with non-absorbable suture, and the wound was cleaned with $10 \%$ povidone-iodine solution.

In control animals, cortical defects of equal size were drilled into the right tibia, but no bacterial inoculum was injected. The drilled holes were sealed with bone wax in all animals. Skin edges were reapproximated with non-absorbable suture, and the wound was cleaned with $10 \%$ povidone-iodine solution.

\section{Pedicled Gastrocnemius Muscle Flap}

Two weeks after induction of osteomyelitis, animals were placed in the supine position, and the same incision was used for tibia exposure. The medial gastrocnemius muscle flap was raised, as described in previous studies. ${ }^{[19]}$ The sural artery branch from the popliteal artery was protected, and the flap was transposed to the proximal tibia (Fig. 2). 


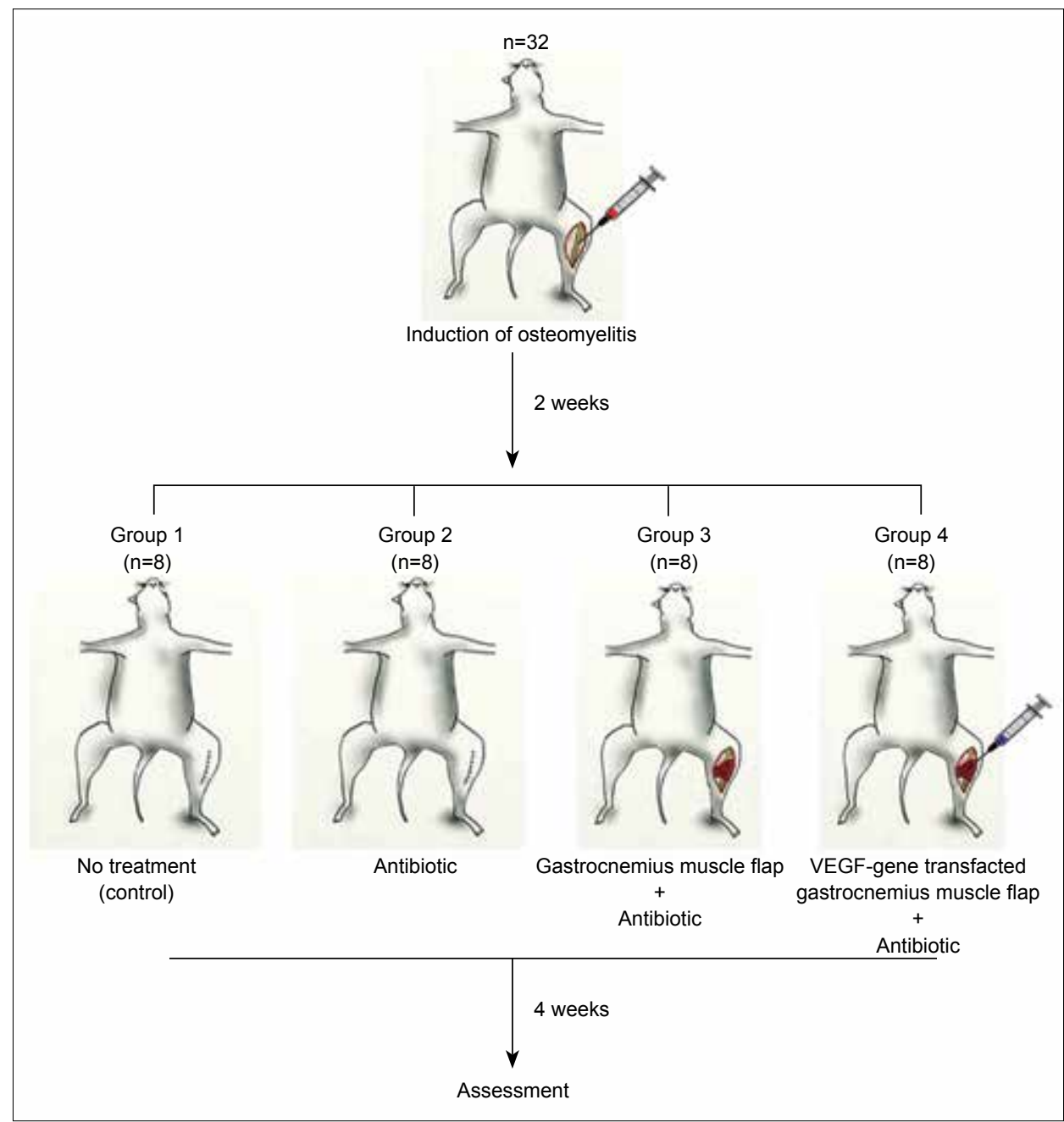

Figure 1. Experimental design.

\section{VEGF gene Preparation and Application}

Plasmids including VEGF [PPI-hVEGF (165)-NEO-DHFR] were obtained from the Ecole Polytechnique Fédérale de Lausanne, as represented by Prof. Patrick Aebischer. The Escherichia coli strain was transfected with this plasmid for proliferation using a TransformAid Bacterial Transformation Kit (ThermoFisher Scientific, Inc., Waltham, MA, USA). Plasmid extraction from transformed E. coli was performed using the Plasmid Giga Kit (Qiagen, Inc., Valencia, CA, USA). Plasmid amount was determined using ultraviolet spectrophotometer. Concentration of plasmid suspended in saline was $1 \mathrm{mg} / \mathrm{mL}$, and it was ready for injection into muscle flaps.

After the muscle flap was elevated, total dose of $0.3 \mathrm{~mL}$ VEGF-DNA-carrying plasmid was injected into the muscle at 3 points in Group 4 animals. The same amount of saline was injected into Group 3 animals.

\section{Detecting Gene Expression}

In order to demonstrate the efficiency of VEGF gene therapy, muscle biopsies were performed on the animals in Groups
3 and 4 on the $3^{\text {rd }}, 7^{\text {th }}$, and $10^{\text {th }}$ postoperative days. Biopsies were obtained from the gastrocnemius muscle. MRNA-pPIhVEGF (165) was evaluated by reverse transcriptase polymerase chain reaction (RT-PCR). For each RNA specimen, dNTP (ThermoFisher Scientific, Inc., Waltham, MA, USA), reverse transcriptase enzyme (ThermoFisher Scientific, Inc.,

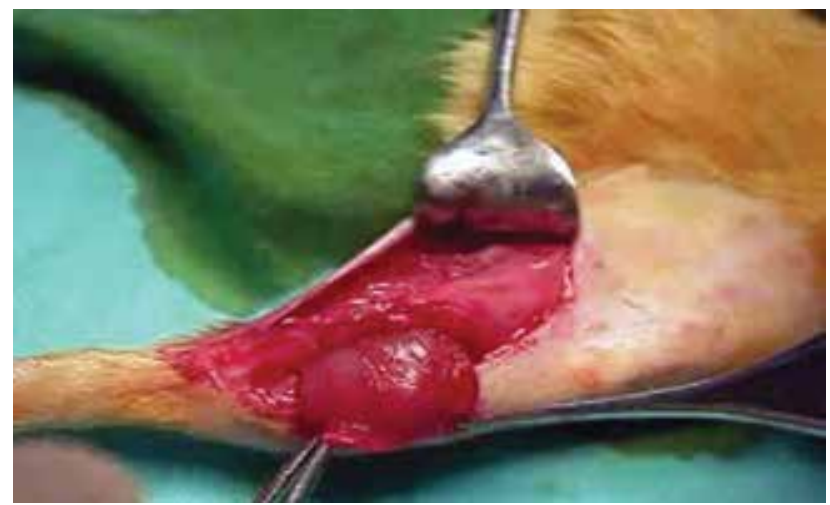

Figure 2. Medial gastrocnemius muscle flap elevation and transposition. 
Waltham, MA, USA), 5XRT buffer (ThermoFisher Scientific, Inc., Waltham, MA, USA), and primer I-containing reaction were used to prepare cDNA. The reaction was incubated at $42^{\circ} \mathrm{C}$ for $60 \mathrm{~min}$ and again at $95^{\circ} \mathrm{C}$ for $5 \mathrm{~min}$, before being terminated. Polymerase chain reaction (PCR) amplification was performed as follows: 35 cycles with 20 seconds at $94^{\circ} \mathrm{C}$, 20 seconds at $55^{\circ} \mathrm{C}, 20$ seconds at $72^{\circ} \mathrm{C}$, and 5 min of incubation at $72^{\circ} \mathrm{C}$. Primers used were $5^{\prime}$-GAGGGCAGAATCATCACGAAGT-3' (from EXON 2, SENSE) and 5'-TGAGAGATCTGGTTCCCGAAAC-3' (from EXON 8, ANTISENSE). Positive controls were used for PCR products. PCR products were analyzed by electrophoresis on $2 \%$ agarose gel $(100 \mathrm{~V}$, 60 minutes) and visualized by ethidium bromide staining.

\section{Assessment}

\section{Scintigraphy With Tc-99m MDP}

For confirmation of osteomyelitis, Group I animals were imaged with triple-phase bone scintigraphy (GE Optima, Milwaukee, WI, USA) 2 weeks after induction. Triple-phase examination of the tibia - consisting of radionuclide angiography (2 sec/frame), blood pool (5 min), and (2-hour) delayed images - were obtained following injection of $1 \mathrm{mCi}$ (37 MBq) Tc-99m methylene di-phosphonate (MDP) in the tail vein. Images of Tc-99m MDP were evaluated by an experienced nuclear medicine physician. A focal area of increased blood flow and osteoblastic activity was considered positive evidence of osteomyelitis.

In a second step, by drawing regions of interest (ROI; diameter $3.0 \mathrm{~mm}$ ) on the osteomyelitis-induced left tibia, as well as on the right tibia, which had been drilled only, a ratio between the number of counts per pixel (cpp) in each region was calculated using transaxial slices. Results were expressed as a tumor: background (T:BG) ratio.

\section{Body Temperature and White Blood Cell Count}

Rectal body temperature of all animals was manually measured at Day $0,7,14,28,35$, and 42. For assessment of white blood cell (WBC) response, I $\mathrm{mL}$ of blood was obtained from the tail vein prior to all surgical procedures, and at 2 and 6 weeks after induction.

\section{Radiology}

Radiographs were taken at 6 weeks after induction. Development and progression of infection was assessed using 5 criteria; ${ }^{[20]}$ periosteal reaction, intraosseous abscess formation, bone deformity, spontaneous fracture, and sequestrum formation. A numerical score was assigned $(0-3$ for the first 3 criteria, 0 - I for the last 2) and the 5 scores were added to make an overall total radiographic score (tRS) for radiological assessment.

\section{Histology}

At 6 weeks after induction, the animals were euthanized, and the left tibia was dissected from the surrounding tissue. After decalcification (5\% formic acid in distilled water for 24 hours), specimens were embedded in paraffin, and multiple 4- $\mu \mathrm{m}$ sections were cut. Sections were stained with hematoxylin-eosin and examined under light microscope. Inflammation and fibrosis were observed. Abscess formation, presence of sequestrum, cortical expansion, and destruction of cortex were used as histological parameters to evaluate samples. ${ }^{[20]}$ Using these criteria, a numerical score was assigned from an answer of "yes" or "no" (I for yes, 0 for no), and the 4 scores were added to make an overall ranking (total histologic score; tHS) for histological assessment.

\section{Statistical Analysis}

Statistical analysis was performed using SPSS software (version 16.0; SPSS Inc., Chicago, IL, USA). All data are presented as mean and SD. Kruskal-Wallis test was used to analyze differences among the experiment groups. Mann-Whitney $U$ test was performed to test the significance of pairwise differences using Bonferroni correction to adjust for multiple comparisons. A value of $p<0.05$ was considered significant.

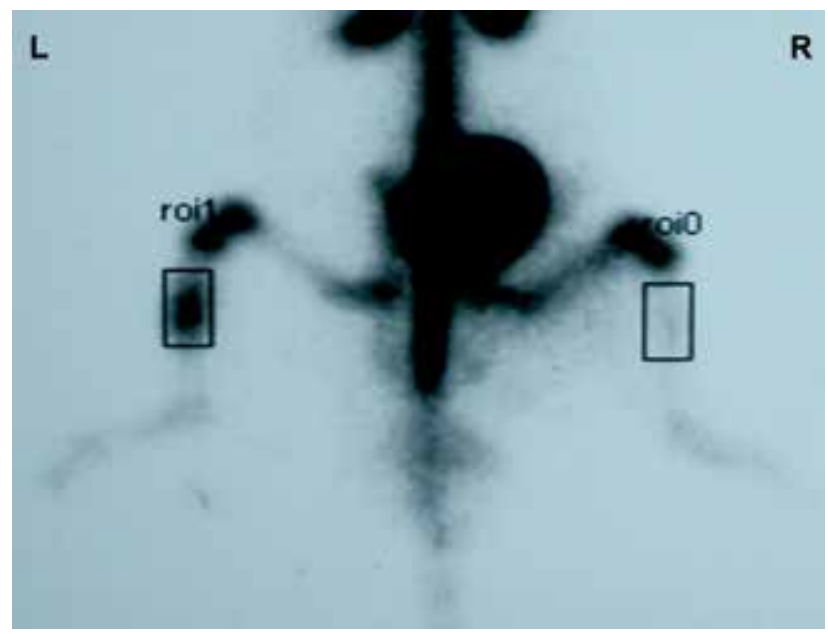

Figure 3. Two-hour delayed images following injection of Tc-99m MDP showed markedly increased activity within the left tibia, compatible with osteomyelitis on posterior planar imaging.

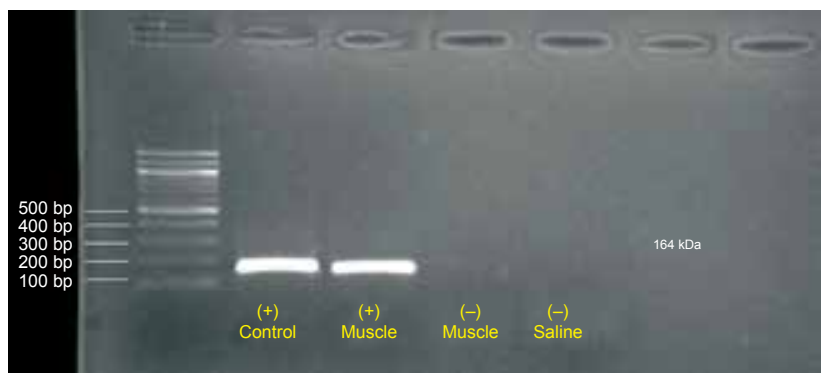

Figure 4. Polymerase chain reaction products were analyzed by electrophoresis on $2 \%$ agarose gel (100V, 60 minutes) and visualized by ethidium bromide staining. SM: Leader; 1: Positive control; 2: Positive muscle; 3: Negative muscle, 4: Negative saline. Bp: Base pair. 


\section{RESULTS}

\section{Scintigraphy With Tc-99m MDP}

Quantitative analysis of scintigraphic data showed values

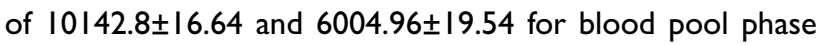
and delayed phase in osteomyelitis-induced left tibias, respectively. Control tibias showed values of $6013.44 \pm 18.48$ and $3187.72 \pm 20.46$ for blood pool phase and delayed phase, respectively. Scintigraphic data revealed significant differences between the left and right tibias in the control animals $(p<0.05$; Fig. 3).

\section{Efficacy of Gene Therapy}

The mRNA-pPI-hVEGF (I65) was determined at the end of electrophoresis by RT-PCR from muscle samples at 3, 7, and 10 postoperative days in the gene therapy group (Group 4; Fig. 4). No band formation was seen in the samples containing negative muscle and serum saline (Group 3). These findings indicate that the gene had been incorporated into the muscle cell in the gene therapy group, and had begun to secrete VEGF.

\section{Body Temperature and White Blood Cell Count}

Preoperatively, mean body temperature and WBC count of all animals were $37.3 \pm 0.4^{\circ} \mathrm{C}$ and $5.43 \pm 1.62 \times 10^{3}$, respectively. Body temperatures and WBC levels prominently increased after 2 weeks from induction. At the $14^{\text {th }}$ day, mean body temperature and WBC count of all animals were $39.1 \pm 0.2^{\circ} \mathrm{C}$ and $18.24 \pm 2.74 \times 10^{3}$, respectively. Mean values of body temperature and WBC count of groups are shown in Figure 5.

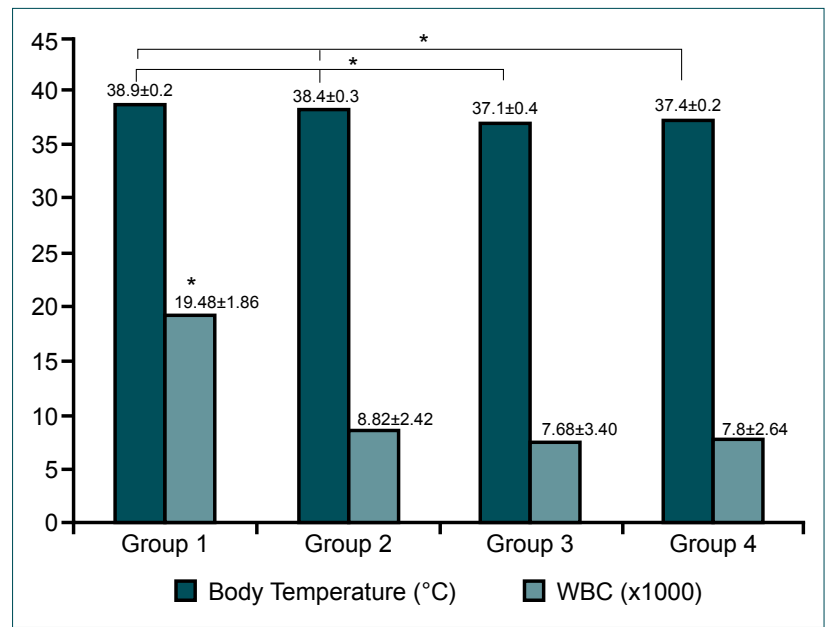

Figure 5. Values (mean $\pm S D$ ) of body temperature and white blood cell count on the $42^{\text {nd }}$ postoperative day. ${ }^{*} p<0.05$.

At the $6^{\text {th }}$ postoperative week, no differences were found in body temperature between Groups I and 2, and Groups 3 and 4. Significant differences were found between Groups I and 3 , and Groups 2 and $3(p<0.05)$. Statistically significant differences were also found between Groups I and 4, and Groups 2 and $4(p<0.05)$.

Regarding WBC count, statistically significant differences were found between Group I and the other groups $(p<0.05)$.

\section{Radiology}

TRSs for radiological severity are shown in Table I. Regarding tRS, no differences were found between Groups I and 2,

Table I. Radiographic criteria and calculated total radiographic scores (mean \pm standard deviation)

\begin{tabular}{lcccc}
\hline & Group I & Group 2 & Group 3 & Group 4 \\
\hline Periosteal reaction & $2.63 \pm 0.52$ & $2.13 \pm 0.64$ & $1.38 \pm 0.74$ & $1.13 \pm 0.64$ \\
Intraosseous abscess formation & $2.75 \pm 0.46$ & $2.75 \pm 0.46$ & $1.50 \pm 0.89$ & $0.38 \pm 0.52$ \\
Bone deformity & $2.75 \pm 0.46$ & $2.62 \pm 0.52$ & $1.75 \pm 0.46$ & $1.63 \pm 0.52$ \\
Spontaneous fracture & $0.50 \pm 0.54$ & $0.38 \pm 0.52$ & 0.00 & 0.00 \\
Sequestrum formation & $0.75 \pm 0.46$ & $0.75 \pm 0.46$ & $0.25 \pm 0.46$ & $0.13 \pm 0.35$ \\
Total radiographic scores & $9.38 \pm 1.19$ & $8.63 \pm 1.19$ & $4.84 \pm 0.92$ & $3.25 \pm 1.28$ \\
\hline
\end{tabular}

Table 2. Histological parameters and calculated Total histological scores (mean \pm standard deviation)

\begin{tabular}{lcccc}
\hline & Group I & Group 2 & Group 3 & Group 4 \\
\hline Abscess formation & $1.00 \pm 0.0$ & $1.00 \pm 0.0$ & $0.54 \pm 0.52$ & $0.25 \pm 0.46$ \\
Presence of sequestrum & $0.75 \pm 0.46$ & $0.63 \pm 0.52$ & $0.25 \pm 0.46$ & $0.13 \pm 0.35$ \\
Cortical expansion & $1.00 \pm 0.0$ & $1.00 \pm 0.0$ & $0.63 \pm 0.52$ & $0.63 \pm 0.52$ \\
Destruction of cortex & $0.88 \pm 0.35$ & $0.63 \pm 0.52$ & $0.25 \pm 0.46$ & $0.13 \pm 0.35$ \\
Total radiographic scores & $3.63 \pm 0.52$ & $3.25 \pm 0.71$ & $1.58 \pm 0.76$ & $1.13 \pm 0.84$ \\
\hline
\end{tabular}




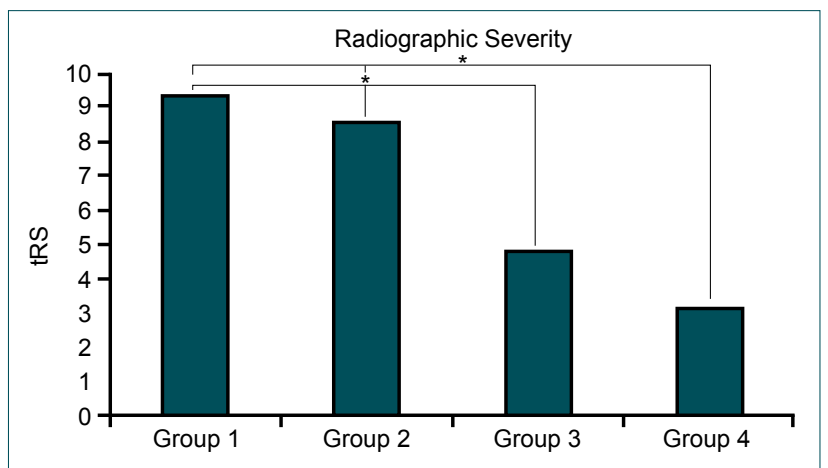

Figure 6. Evaluation of total radiographic scores showed statistically significant differences between the muscle flap (Group 3 and 4) and other groups (Groups 1 and 2). tRS: Total radiographic score; ${ }^{*} p<0.05$.

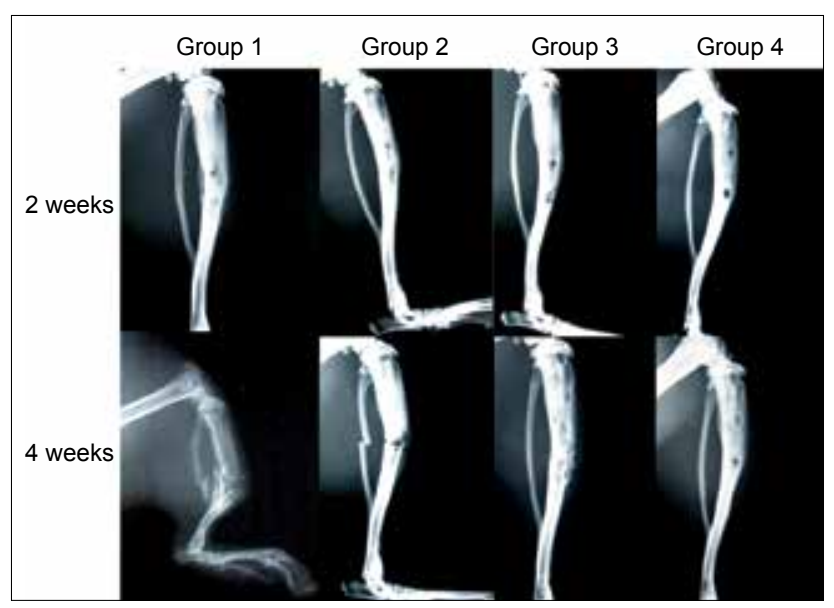

Figure 7. Radiologic images of each group taken at the $2^{\text {nd }}$ and $4^{\text {th }}$ weeks after induction of osteomyelitis (upper and lower rows, respectively).

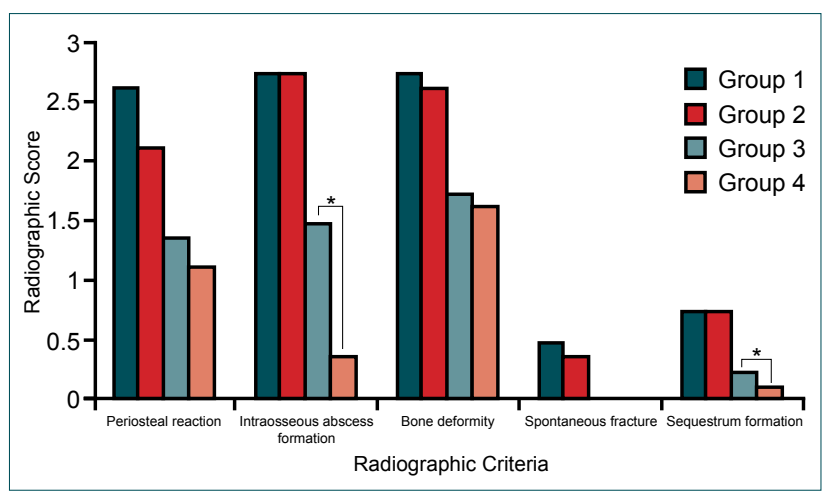

Figure 8. Comparison of radiographic criteria. Regarding intraosseous abscess and sequestrum formation, significant differences were found between Groups 3 and $4 .{ }^{*} p<0.05$.

and Groups 3 and 4. In addition, significant differences were found between Groups I and 3, Groups I and 4, Groups 2 and 3, and Groups 2 and 4 ( $p<0.05$; Figs. 6, 7). Regarding intraosseous abscess and sequestrum formation, statistically significant differences were found between Group 4 and the other groups ( $p<0.05$; Fig. 8).

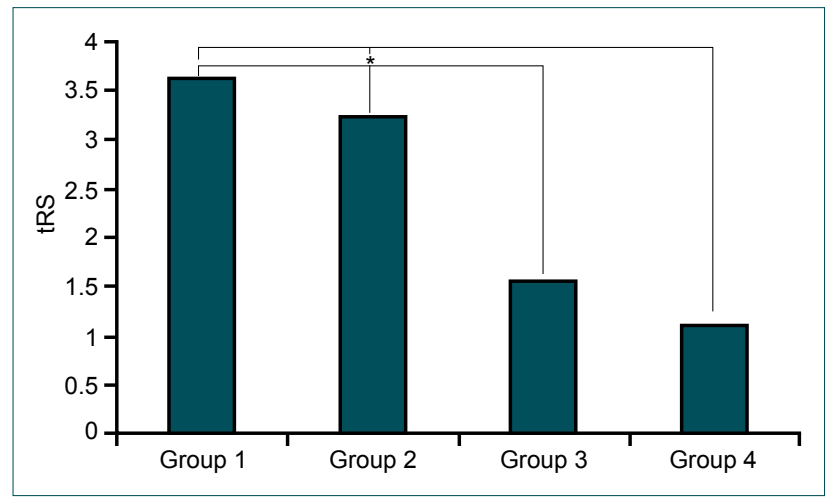

Figure 9. Evaluation of total histologic scores showed statistically significant differences between the muscle flap (Groups 3 and 4 ) and other groups (Groups 1 and 2). tHS: Total histologic score; ${ }^{*} p<0.05$.

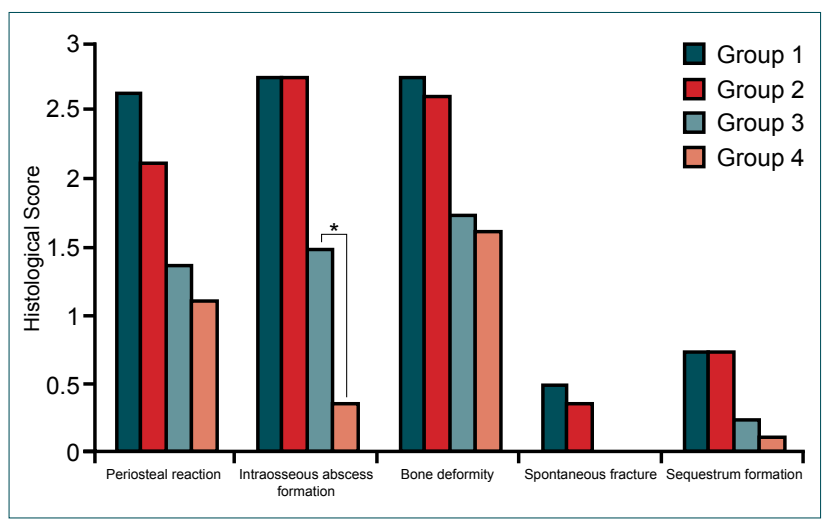

Figure 10. Histologic criteria of intraosseous abscess formation was significantly higher in Group 3, compared to Group 4. * $p<0.05$.

\section{Histology}

tHSs are shown in Table 2. Regarding tHS, no differences were found between Groups I and 2, and Groups 3 and 4. Significant differences were found between Groups I and 3, Groups I and 4, Groups 2 and 3, and Groups 2 and 4 ( $p<0.05$; Fig. 9). Less inflammation and more fibrosis was found in Group 4, compared to Group 3. In terms of abscess formation, statistically significant differences were found between Group 4 and the other groups $(p<0.05$; Figs. 10,11$)$.

\section{DISCUSSION}

Understanding of the underlying mechanism of a disease is crucial for development of new treatment modalities. The process of osteomyelitis is initiated by the causative microorganism and inflammation, and continues with vascular insufficiency. The resulting ischemia contributes to bone necrosis. [1,2] Current treatment modalities for osteomyelitis include combined antimicrobial therapy, and surgical approach for causative pathogen and devitalized tissue. However, it can be persistent for years, with frequent therapeutic failure. In spite of advances in both antibiotics and surgical treatment, the long-term recurrence rate remains approximately $20-30 \%{ }^{[21]}$ Due to dissatisfaction with actual treatment modalities, many 

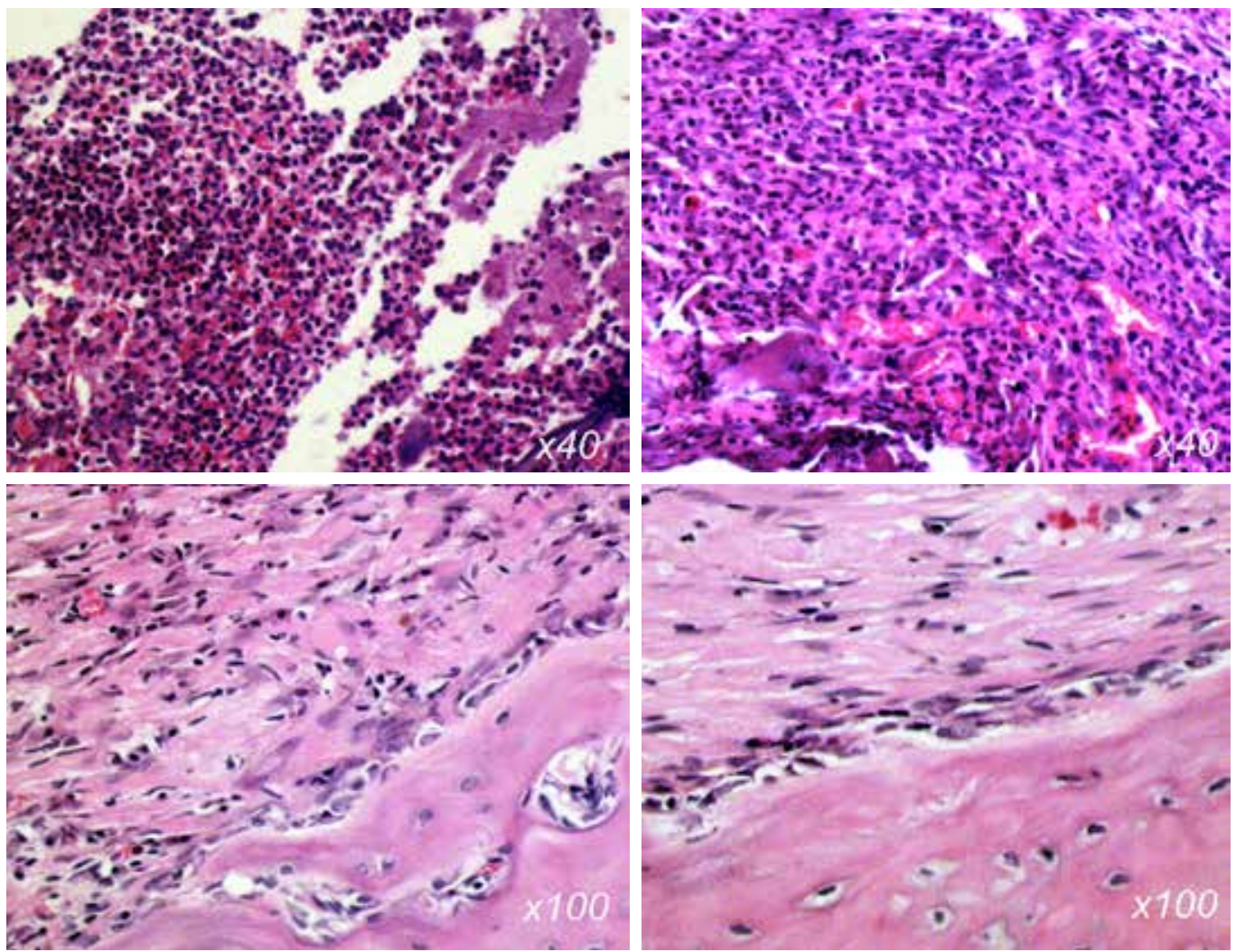

Figure 11. Histologic examination with hematoxylin-eosin stain (x40, x100). Marked polymorphonuclear leukocyte infiltration was observed in Groups 1 and 2 (upper left and right, respectively). Compared to Group 3, less inflammation and more fibrosis were observed in Group 4 (lower left and right, respectively).

experimental and clinical approaches to osteomyelitis therapy have been described in the literature. ${ }^{[22-25]}$

Coverage of the defect with well-vascularized tissue, providing sufficient blood supply to the devitalized bone, is another important modality for the treatment of osteomyelitis. In addition to appropriate antimicrobial therapy, defect reconstruction and optimization of local microcirculation is essential in the preservation of limbs and attainment of functional results. Damage to the periosteum results in impaired blood supply to the bone, and eventually, larger bone areas become necrotic as the disease advances. Therefore, in addition to antimicrobial therapy, a more comprehensive approach to treatment of osteomyelitis should include improvement of circulation.

VEGF gene-transfected muscle flap was used in the present experimental management of osteomyelitis. In terms of radiographic and histological scores, no differences were found between Group I (no treatment) and Group 2 (antibiotic treatment). These findings confirm that antimicrobial therapy alone is not effective management of osteomyelitis in an experimental setting. Moreover, significant differences were found between the groups in which muscle flaps were used (Groups 3 and 4) and not used (Groups I and 2). In terms of body temperature, the same results were observed. These findings verify that muscle flaps are effective reconstructive tools for controlling infection and the progress of osteomyelitis.

Due to the several drawbacks of use of growth factor in the therapeutic purposes (enzymatic inactivation, low bio-availability, the need for an exogenous carrying molecule), gene therapy has been adopted to achieve lasting effects. ${ }^{[26]}$ The idea to use VEGF for gene therapy of osteomyelitis was first put forth by Jon Mader. ${ }^{[3]}$ However, no research regarding the effects this treatment have yet been published. VEGF gene therapy has been used to improve flap viability with promising results in experimental settings. ${ }^{[27,28]}$ In the present study, VEGF gene therapy was administered by intramuscular injection to the muscle flap in order to create a VEGF-enriched microenvironment in osteomyelitis-induced bone. In histological examination, less inflammation and more fibrosis was found in the VEGF gene-transfected muscle flap group (Group 4), compared to the group that received muscle flap without VEGF gene-transfection (Group 3). In addition, intraosseous abscess formation was found to be significantly lower in Group 4, compared to other groups in both radiological and histological analysis. According to these findings, it is believed that ideal blood supply to the damaged area was achieved with VEGF-transfected muscle flap.

Different methods for the administration of VEGF gene ther- 
apy have been described. Studies have shown that adenovirus vector inserted with VEGF or liposome-mediated VEGF gene are effectively transferred and expressed via direct intramuscular injection or arterial access. ${ }^{[29,30]}$ However, in addition to gene delivery techniques, the simplest method of gene delivery is the direct injection of naked plasmid DNA into tissues. Advantages of this method are local delivery to the target organ and the ability to act on non-dividing cells. The skeletal muscle has been shown to be suitable for taking up and expressing foreign genes transferred in the form of naked plasmid DNA. ${ }^{[31]}$ In order to show transfection efficacy, muscle biopsies were presently performed in the postoperative period, and VEGF mRNA expression was detected by reverse transcriptase-PCR in Group 4.

For the diagnosis of osteomyelitis, clinical examination and imaging studies are used. ${ }^{[I]}$ Plain $x$-rays, nuclear scintigraphy, and magnetic resonance imaging (MRI) are common imaging tools for diagnosis. However, because of the high cost of MRI, nuclear scintigraphy and plain $\mathrm{x}$-rays were used in the present study for diagnosis and follow-up. For confirmation of osteomyelitis, scintigraphy with Tc-99m MDP was applied to the Group I animals 14 days after the induction of osteomyelitis. Quantitative analysis of the scintigraphic data showed the differences between osteomyelitis-induced left and drilled-only right (control) tibias. Plain films were easily applied to the animals and used as a screening and assessment tool.

A number of parameters for monitoring the activity of osteomyelitis exist in the literature. ${ }^{[1,32]}$ In general, they can be divided into 4 subgroup: hematologic, clinical, radiological and histological. Although radiological in combination with histological parameters were of primary use, clinical and hematological parameters were also used. Several systemic hematological parameters, such as erythrocyte sedimentation rate, C-reactive protein, and procalcitonin, are available to monitor response to therapy. In spite of some differences in specificity and sensitivity, all adequately contribute to assessment and follow-up of osteomyelitis. ${ }^{[32]}$ In the present study, the activity of the osteomyelitis was monitored with WBC counts and rectal body temperature as hematological and clinical parameters, respectively. However, the more detailed parameters for assessment of treatment may be used in future studies.

Well-known scoring systems were utilized for radiological and histological evaluation in the present study. ${ }^{[20]}$ Although in terms of tRS and tHS, no differences were found between Group 3 (without VEGF gene transfection) and Group 4 (administered VEGF gene-transfected muscle flap), some important parameters of each scoring systems were found to be statistically different. According to radiological evaluation, intraosseous abscess and sequestrum formation were found to be significantly lower in Group 4, compared to the other groups. In terms of intraosseous abscess formation, the same result was achieved in histological evaluation. This is an important finding for the treatment of osteomyelitis and prevention of its progression.

In the pathogenesis of the disease, intraosseous abscess and sequestrum formation occur in the later stages. ${ }^{[33]}$ Initially, bacterial toxin production and host response result in the release of lytic enzymes. This, in turn, damages the medullar cavity and the bone cortex...$^{[3]}$ Ensuing damage of the periosteum impairs the blood supply to the cortical and medullar bone, and larger areas of ischemic bone tissue become necrotic. Eventually, purulent material and impaired blood supply contribute to the formation of abscess and sequestrum, respectively. In addition, sequestrum is the best stimulant for proper involucrum formation, which can be seen in more advanced stages. ${ }^{[33]}$ Compared to the other groups, decreased formation of abscess and sequestrum in Group 4 indicates that the treatment of VEGF gene-transfected muscle flap prevents the progression of the disease. The differences found in Group 4 can most likely be attributed to the effect of VEGF gene therapy. Accordingly, it is presently suggested that VEGF gene-transfected muscle flap could provide ideal local microcirculation, allowing for proper antibiotic delivery and a desired healing process in experimental settings.

It is known that antibiotic therapy is a critical component of osteomyelitis treatment protocol. However, systemically administered antibiotics cannot reach the osteomyelitis sites in sufficient concentration, due to lack of appropriate circulation. For that reason, various studies of appropriate antimicrobial therapy have been conducted. Photodynamic therapy was used by dos Reis JA et al.," ${ }^{[22]}$ who found that photodynamic antimicrobial therapy was effective in reducing the number of $S$. Aureus in both in vitro and in vivo studies. In vitro antibacterial activity of the bioglass (BAG S53P4) against multiresistant microorganisms commonly involved in osteomyelitis was studied by Drago L. et al. ${ }^{[23]}$ In addition, the authors evaluated its use in surgical adjunctive treatment of osteomyelitis in a prospective study of 27 patients with clinically and radiologically diagnosed osteomyelitis. In vitro tests regarding the antibacterial activity of BAG S53P4 revealed marked bactericidal activity and clinically no signs of infection were observed in 24 patients during follow-up, while infection recurrence was observed in 2 subjects. Similarly, a drug delivery system has been developed by Bhattacharya R. et al. in an effort to combat the causative agent. ${ }^{[2]}$ After inducing osteomyelitis, hydroxyapatite scaffolds impregnated with antibiotic ceftriaxone-sulbactam sodium were utilized in rabbit tibia. Efficient drug release of up to 42 days and infection eradication were observed. In terms of antibacterial efficiency and disease control, promising results were reported in all of these studies. Achievement of ideal antimicrobial agent delivery is one of the important contributions of VEGF gene therapy.

Debridement is an approach commonly used in the clinic to treat existing osteomyelitis. The surgical removal of necrotic bone and infected tissue improve healing potential. Due to 
the size limitations of our experimental model (small bone dimensions), debridement was not included in the experiment design. However, it is important to point out that VEGF genetransfected muscle flap could provide effective control of the disease even without debridement. Debridement should be included in large animal models, as well in further studies.

In conclusion, it has been shown that VEGF gene-transfected muscle flap is an effective means of preventing progression of osteomyelitis to advanced stages, and is also an efficient component of treatment, due to its promotion of circulation.

\section{Financial Interest}

None

\section{Conflict of interest: None declared.}

\section{REFERENCES}

1. Lew DP, Waldvogel FA. Osteomyelitis. Lancet 2004;364:369-79. Crossref

2. Rao N, Ziran BH, Lipsky BA. Treating osteomyelitis: antibiotics and surgery. Plast Reconstr Surg 2011;127 Suppl 1:177-87. Crossref

3. Ross JJ. Angiogenic gene therapy as a potential therapeutic agent in chronic osteomyelitis. Med Hypotheses 2006;67:161-3. Crossref

4. Tice AD, Hoaglund PA, Shoultz DA. Risk factors and treatment outcomes in osteomyelitis. J Antimicrob Chemother 2003;51:1261-8. Crossref

5. Anthony JP, Mathes SJ, Alpert BS. The muscle flap in the treatment of chronic lower extremity osteomyelitis: results in patients over 5 years after treatment. Plast Reconstr Surg 1991;88:311-8. Crossref

6. Fitzgerald RH Jr, Ruttle PE, Arnold PG, Kelly PJ, Irons GB. Local muscle flaps in the treatment of chronic osteomyelitis. J Bone Joint Surg Am 1985;67:175-85.

7. Mathes SJ. The muscle flap for management of osteomyelitis. N Engl J Med 1982;306:294-5. Crossref

8. Zumiotti AV, Teng HW, Ferreira MC. Treatment of post-traumatic tibial osteomyelitis using microsurgical flaps. J Reconstr Microsurg 2003;19:163-71. Crossref

9. Costa H, Malheiro E, Silva A, Fidalgo R, Trigo J. The distally based posterior tibial myofasciocutaneous island flap in foot reconstruction. Br J Plast Surg 1996;49:111-4. Crossref

10. Murphy RC, Robson MC, Heggers JP, Kadowaki M. The effect of microbial contamination on musculocutaneous and random flaps. J Surg Res 1986;41:75-80. Crossref

11. Hiltunen MO, Ruuskanen M, Huuskonen J, Mähönen AJ, Ahonen M, Rutanen J, et al. Adenovirus-mediated VEGF-A gene transfer induces bone formation in vivo. FASEB J 2003;17:1147-9. Crossref

12. Peng H, Wright V, Usas A, Gearhart B, Shen HC, Cummins J, Huard J. Synergistic enhancement of bone formation and healing by stem cell-expressed VEGF and bone morphogenetic protein-4. J Clin Invest 2002;110:751-9. Crossref

13. Street J, Bao M, deGuzman L, Bunting S, Peale FV Jr, Ferrara N, et al. Vascular endothelial growth factor stimulates bone repair by promoting angiogenesis and bone turnover. Proc Natl Acad Sci U S A 2002;99:9656-61. Crossref

14. Pang Y, Lineaweaver WC, Lei MP, Oswald T, Shamburger S, Cai Z, et al. Evaluation of the mechanism of vascular endothelial growth factor improvement of ischemic flap survival in rats. Plast Reconstr Surg 2003;112:556-64. Crossref

15. Machens HG, Salehi J, Weich H, Münch S, Siemers F, Krapohl BD, et al.
Angiogenic effects of injected VEGF165 and sVEGFR-1 (sFLT-1) in a rat flap model. J Surg Res 2003;111:136-42. Crossref

16. Shenaq SM, Rabinovsky ED. Gene therapy for plastic and reconstructive surgery. Clin Plast Surg 1996;23:157-71.

17. Takeshita S, Isshiki T, Ochiai M, Eto K, Mori H, Tanaka E, et al. Endothelium-dependent relaxation of collateral microvessels after intramuscular gene transfer of vascular endothelial growth factor in a rat model of hindlimb ischemia. Circulation 1998;98:1261-3. Crossref

18. Mäkinen TJ, Lankinen P, Pöyhönen T, Jalava J, Aro HT, Roivainen A. Comparison of 18F-FDG and 68Ga PET imaging in the assessment of experimental osteomyelitis due to Staphylococcus aureus. Eur J Nucl Med Mol Imaging 2005;32:1259-68. Crosstef

19. Tonken HP, Zhang F, Sudekum AE, Siko PP, Newlin L, Partington MT, et al. Microvascular transplant of the gastrocnemius muscle in rats. Microsurgery 1993;14:120-4. Crossref

20. An YH, Friedman RJ. Animal models of orthopedic implant infection. J Invest Surg 1998;11:139-46. Crossref

21. Conterno LO, da Silva Filho CR. Antibiotics for treating chronic osteomyelitis in adults. Cochrane Database Syst Rev 2009;3:CD004439. Crossref

22. dos Reis JA Jr, de Carvalho FB, Trindade RF, de Assis PN, de Almeida PF, Pinheiro AL. A new preclinical approach for treating chronic osteomyelitis induced by Staphylococcus aureus: in vitro and in vivo study on photodynamic antimicrobial therapy (PAmT). Lasers Med Sci 2014;29:789-95. Crossref

23. Drago L, Romanò D, De Vecchi E, Vassena C, Logoluso N, Mattina R, et al. Bioactive glass BAG-S53P4 for the adjunctive treatment of chronic osteomyelitis of the long bones: an in vitro and prospective clinical study. BMC Infect Dis 2013;13:584. Crossref

24. Bhattacharya R, Kundu B, Nandi SK, Basu D. Systematic approach to treat chronic osteomyelitis through localized drug delivery system: bench to bed side. Mater Sci Eng C Mater Biol Appl 2013;33:3986-93. Crossref

25. Uskoković V, Desai TA. Phase composition control of calcium phosphate nanoparticles for tunable drug delivery kinetics and treatment of osteomyelitis. II. Antibacterial and osteoblastic response. J Biomed Mater Res A 2013;101:1427-36. Crossref

26. Tepper OM, Mehrara BJ. Gene therapy in plastic surgery. Plast Reconstr Surg 2002;109:716-34. Crossref

27. Zhang F, Yang F, Hu EC, Sones W, Lei M, Lineaweaver WC. Vascular endothelial growth factor gene therapy in improvement of skin paddle survival in a rat TRAM flap model. J Reconstr Microsurg 2005;21:3916. Crossref

28. de Freitas AL, Gomes HC, Lisboa BC, Arias V, Han SW, Ferreira LM. Effect of gene therapy with vascular endothelial growth factor after abdominoplasty on TRAM flap viability in a rat model. Plast Reconstr Surg 2010;125:1343-51. Crossref

29. Lubiatowski P, Gurunluoglu R, Goldman CK, Skugor B, Carnevale K, Siemionow M. Gene therapy by adenovirus-mediated vascular endothelial growth factor and angiopoietin-1 promotes perfusion of muscle flaps. Plast Reconstr Surg 2002;110:149-59. Crossref

30. Neumeister MW, Song YH, Mowlavi A, Suchy H, Mathur A. Effects of liposome-mediated gene transfer of VEGF in ischemic rat gracilis muscle. Microsurgery 2001;21:58-62. Crossref

31. Yang LW, Zhang JX, Zeng L, Xu JJ, Du FT, Luo W, et al. Vascular endothelial growth factor gene therapy with intramuscular injections of plasmid DNA enhances the survival of random pattern flaps in a rat model. Br J Plast Surg 2005;58:339-47. Crossref

32. Michail M, Jude E, Liaskos C, Karamagiolis S, Makrilakis K, Dimitroulis $\mathrm{D}$, et al. The performance of serum inflammatory markers for the diagnosis and follow-up of patients with osteomyelitis. Int J Low Extrem Wounds 2013;12:94-9. Crossref

33. Vinod Kumar BP. Osteomyelitis; an overview. Kerala Journal of Orthopaedics 2013;26:70-6. 


\title{
Deneysel osteomyelit tedavisinde vasküler endotelial büyüme faktörü geni ile transfekte edilmiş transpozisyonel kas flebinin etkinliği
}

\author{
Dr. Mahir Aliyev, ${ }^{1}$ Dr. Andaç Aykan, ${ }^{2}$ Dr. Muhitdin Eski, ${ }^{2}$ Dr. Nuri Arslan, ${ }^{3}$ Dr. Bülent Kurt, ${ }^{4}$ Dr. Mustafa Şengezer ${ }^{2}$
}

\author{
${ }^{1}$ Asker Hastanesi, Plastik, Rekonstrüktif ve Estetik Cerrahi Kliniği, Bakü, Azerbaycan \\ ${ }^{2}$ Gülhane Askeri Tıp Akademisi, Plastik, Rekonstrüktif ve Estetik Cerrahi Anabilim Dalı, Ankara \\ ${ }^{3}$ Gülhane Askeri Tıp Akademisi, Nükleer Tıp Anabilim Dalı, Ankara \\ ${ }^{4}$ Gülhane Askeri Tıp Akademisi, Patoloji Anabilim Dalı, Ankara
}

AMAÇ: Bu çalışma, vasküler endotelyal büyüme faktörünün (VEGF) kemik iyileşmesi ve formasyonu üzerine anjiyogenetik ve indükleyici etkisine dayanarak, deneysel olarak oluşturulmuş osteomyelitte VEGF gen uygulamasının etkinliğini araştırmak için dizayn edildi.

GEREÇ VE YÖNTEM: Bu amaçla 32 adet erkek Sprague-Dawley cinsi sıçanın sol tibiasında osteomyelit oluşturuldu ve denekler dört eşit gruba ayrıldı. Birinci grupta (kontrol grubu, $n=8$ ) dört hafta süre ile hiçbir tedavi uygulanmadı. İkinci grupta $(n=8)$ dört hafta antibiyotik tedavisi uygulandı. Üçüncü grupta $(n=8)$ proksimal pediküllü medial gastroknemius kas flebi osteomyelit alanına transpoze edildi ve dört hafta antibiyotik tedavisi uygulandı. Dördüncü grupta $(n=8)$ ise proksimal pediküllü medial gastroknemius kas flebi osteomyelit alanına transpoze edildikten sonra plazmid içinde VEGF DNA'sı kas içine enjekte edildi ve dört hafta antibiyotik tedavisi uygulandı. Tüm gruplarda vücut ısısı, kan beyaz küre sayısı incelendi, osteomyelit oluşturulan kemikler radyolojik ve histolojik açıdan değerlendirildi.

BULGULAR: Vücut IIISI ve lökositoz değerleri kontrol grubunda sürekli yüksekken, ikinci, üçüncü ve dördüncü gruplarda ise tedavinin üçüncü haftasında normal seviyelere döndüğü bulundu. Radyolojik ve histolojik değerlerin toplam skorlarının istatistiksel analizinde I-3, I-4, 2-3, ve 2 ile 4 . gruplar arasında anlamlı fark tespit edildi $(p<0.05)$. Radyolojik parametrelerden sadece apse ve sekestrum, histolojik parametrelerden ise sadece apse oluşumu açısından dördüncü grup ve diğer gruplar arasında anlamlı fark saptandı $(p<0.05)$.

TARTIŞMA: Elde edilen bulgular, VEGF geni ile transfekte edilmiş kas flebinin, deneysel olarak, osteomyelit tedavisinde etkin olduğunu göstermiştir. Anahtar sözcükler: Gastrokinemius; kas flebi; osteomyelit; transfeksiyon; VEGF; VEGF geni.

Ulus Travma Acil Cerrahi Derg 2016;22(3):205-214 doi: 10.5505/tjtes.2015.37888 